\title{
PERFORMA LAJU PERTUMBUHAN IKAN BANDENG (Chanos chanos) YANG DIBERIKAN PAKAN DENGAN PENGKAYAAN PROBIOTIK
}

\author{
Linayati'), Tegar Aji Prasetyo $^{1)}$, Tri Yusufi Mardiana ${ }^{3)}$ \\ 1,2,3 FakultasPerikanan, UniversitasPekalongan \\ email: pattyana95ina@yahoo.co.id
}

\begin{abstract}
Research objective to find out the optimal growth of milkfish seeds by giving probiotic with different doses.This research was conducted on Agust $15^{\text {th }}$-September $14 t^{h}$, 2020 and is located at Marine and Brackish Water Laboratory, Faculty of Fisheries, Pekalongan University. The test fish used in this study was the 2,5 cm milkfish seeds obtained from fish farm's from Pekalongan City. The research was carried out on a laboratory scale and the experimental design applied was completetely randomized design (CRD) which included 5 treatments and 3 replications, namely $A$ (control), B (5 ml/kg of feed), C (10 ml/kg feed), D (15 ml/kg feed) and E (20 ml/kg feed).In order to find out the response ofthe growth of milk fish seeds to the addition of probiotic with different doses, a tukey test was performed. The highest growth of milkfish was obtained in treatment $D$ that was $10,82 \mathrm{gr}$, then followed by treatment $C$ was $9,97 \mathrm{gr}$, treatment $B$ was $9,38 \mathrm{gr}$, treatment $E$ was $8,99 \mathrm{gr}$ and the lowest was in treatment $\mathrm{A}$ which was 7,73 $\mathrm{gr}$. The results of the analysis of variance is known that the calculated $F$ value is greater than the $F$ table, which means the addition of probiotic with different doses has a very significant effect on the growth of milkfish seeds.
\end{abstract}

Keywords: Probiotic,milkfish, growth

\section{PENDAHULUAN}

Ikan bandeng (Chanos chanos) termasuk dalam kategori ikan ekonomis penting, karena di tingkat domestik permintaan masyarakat terhadap ikan bandeng cukup tinggi. Nilai kandungan gizinya yang cukup tinggi dengan rasa yang gurih membuatnya digemari oleh berbagai kalangan. Pemeliharaan ikan bandeng juga relatif mudah. Hal itu menyebabkan ketertarikan banyak pihak untuk membudidayakan ikan bandeng baik secara tradisional maupun modern.

Beberapa hal penting dalam budidaya adalah penyediaan benih dan pakan yang terjamin secara kuantitas dan kualitas. Kedua hal tersebut sangat penting dalam kaitannya meningkatkan produksi budidaya. Benih ikan bandeng atau sering disebut sebagai nener harus memenuhi kriteria sehat di antaranya tidak ada luka, siripnya utuh, gerakannya aktif (Alifuddin, 2003). Pakan harus mengandung nutrisi yang sesuai dengan kebutuhan ikan seperti karbohidrat, lemak, protein, mineral dan vitamin (Kordi,2009). Permasalahan yang sering dihadapi pembudidaya adalah penyediaan pakan buatan. Pakan buatan dengan harga yang cukup mahal menyebabkan biaya produksi menjadi tinggi. Menurut Rasidi (1998), biaya pakan dapat mencapai $60-70 \%$ dari komponen biaya produksi. Untuk itu perlu dilakukan usaha meningkatkan efisiensi pakan dengan peningkatan serapan nutrisi dalam pakan. Ikan bandeng sendiri memerlukan protein yang cukup tinggi untuk pertumbuhannya. Selain kandungan protein yang harus sesuai dengan kebutuhan ikan bandeng, nutrisi yang lain juga harus tersedia. Salah satu usaha untuk meningkatkan nilai nutrisi pada pakan ikan dapat dilakukan dengan cara menambahkan probiotik pada pakan (Iribarrren et al., 2012).

Putra (2010) menyebutkan bahwa pemberian probiotik dapat meningkatkan efisiensi pakan karena pakan akan lebih mudah dicerna. Selanjutnya disebutkan pula bahwa probiotik juga membantu enzim pencernaan agar dapat bekerja lebih efektif. Berdasarkan uraian di atas perlu dilakukan penelitian tentang 
penggunaan probiotik pada pakan komersil guna meningkatkan nilai kuantitas pada budidaya ikan bandeng yaitu pertumbuhan, feed convention ratio, dan tingkat kelulushidupan ikan tersebut.

Tujuan penelitian ini untuk mengukur laju pertumbuhan ikan bandeng yang telah diberikan pakan yang diperkaya probiotik dan mengetahui dosis probiotik yang tepat dalam budidaya ikan bandeng.

\section{TINJAUAN PUSTAKA}

Pemanfaatan mikroorganisme untuk meningkatkan usaha budidaya ikan telah banyak dilakukan, terutama pemanfaatan probiotik. Probiotik sendiri menurut Elumalai et al, (2013) adalah mikroorganisme hidup dalam budidaya ikan yang dapat mencegah penyakit, sehingga meningkatkan produksi dan menurunkan kerugian ekonomi. Kandungan yang ada dalam probiotik secara umum terdiri dari berbagai macam bakteri yang menguntungkan dan juga bahan tambahan lainnya seperti vitamin, mineral maupun imunostimulan. Probiotik memiliki efek anti mikrobial yang berperan untuk pengendalian patogen di saluran pencernaan. Mikroorganisme yang bersifat baik ini bersaing dengan patogen dalam saluran pencernaan. Hal tersebut mencegah patogen mengambil nutrisi yang diperlukan ikan (Cruz et al., 2012). Kondisi ini menyebabkan nutrisi lebih mudah diserap oleh ikan sehingga meningkatkan efisiensi pakan dan juga pertumbuhan.

Penambahan probiotik pada pakan juga dapat meningkatkan sistem kekebalan tubuh dan memiliki pengaruh positif terhadap keberlangsungan hidup ikan. Hal ini didukung pendapat dari Iribarren et al. (2012) yang menyatakan bahwa penggunaan probiotik dapat meningkatkan tingkat kelulushidupan dan daya tahan tubuh ikan terhadap infeksi patogen. Peningkatan sistem kekebalan non spesifik pada ikan dapat ditunjukkan dengan meningkatnya jumlah leukosit dalam darah. Hal ini sesuai dengan pendapat Septiarini et al, (2012) yang menyatakan adanya peningkatan jumlah leukosit pada ikan yang telah diberi probiotik pada saat diserang oleh bakteri Aermonas Salmonicida.
Penggunaan beberapa jenis bakteri dalam probiotik seperti Bacillus sp dan Lactobacillus $s p$ pada budidaya udang dan ikan memberikan hasil yang positif, terutama pada pertumbuhan. Jenis Bacillus sp sebagai prebion dapat digunakan untuk memperbaiki kualitas air dengan cara menjaga keseimbangan populasi mikroba. Selain itu bakteri tersebut juga secara bersamaan mengurangi pertumbuhan patogen dan menjaga kesehatan hewan inang (Wang et al., 1999 dalam Irianto, 2003).

Secara teknis, penggunaan probiotik pada ikan dapat memberikan banyak manfaat, antara lain dapat memperbaiki mikroflora dalam pencernaan, meningkatkan kinerja enzim pencernaan sehingga penyerapan makanan dapat ditingkatkan. Selain itu, probiotik dapat membantu memperbaiki dan menjaga kualitas air budidaya. Hal ini dapat disebabkan karena dalam probiotik terdapat pula bakteri yang berperan dalam proses nitrifikasi dan denitrifikasi dalam air. Probiotik dapat pula memperbanyak jumlah pakan alami dalam air budidaya sehingga membantu ketersediaan pakan alami di kolam ataupun tambak. Komposisi probiotik di antaranya adalah terdiri dari Lactobacillus plantarum, Nitrosomonas europea, Bacillus subtilis, Bacillus apiarius, molase, mineral, aquades.

\section{METODE PENELITIAN}

Penelitian dilaksanakan pada tanggal $1 \mathrm{Juli}$ 2020 sampai 30 Juli 2020 di Laboratorium Budidaya Perairan, Prodi Budidaya Perairan, Fakultas Perikanan, Universitas Pekalongan. Rancangan percobaan yang digunakan yaitu Rancangan Acak Lengkap (RAL) yang terdiri dari lima perlakuan dan tiga ulangan dengan pemberian probiotik dengan dosis yang berbeda. Perlakuan yang digunakanyaitu : A) 0 $\mathrm{ml} / \mathrm{L}$ probiotik dalam $1 \mathrm{~kg}$ pakan, B) $5 \mathrm{ml} / \mathrm{L}$ probiotik dalam $1 \mathrm{~kg}$ pakan, C) $10 \mathrm{ml} / \mathrm{L}$ probiotik dalam $1 \mathrm{~kg}$ pakan, D) $15 \mathrm{ml} / \mathrm{L}$ probiotik dalam $1 \mathrm{~kg}$ pakan dan E) $20 \mathrm{ml} / \mathrm{kg}$ probiotik dalam $1 \mathrm{~kg}$ pakan. Dosis yang digunakan mengacu pada penelitian terdahulu yaitu Agustini dan Muhajir (2018) yang memberikan probiotik Petrofish pada ikan nila. Benih ikan bandeng dalam penelitian ini dipelihara selama 4 minggu. 
Indikator pertumbuhan yang akan diuji adalah pertambahan biomasa mutlak ikan bandeng dihitung menggunakan rumus Effendi (1997) sebagai berikut :

$$
\mathbf{W}=\mathbf{W t}-\mathbf{W 0}
$$

Keterangan :

W : Pertumbuhan biomassa mutlak benihi ikan bandeng $(\mathrm{g})$

Wt : Biomassa benih ikan bandeng pada akhir penelitian $(\mathrm{g})$

W0 : Biomassa benih ikan bandeng pada awal penelitian $(\mathrm{g})$

Untuk indikator pertumbuhan spesifik menggunakan rumus Yanti et al., (2013) sebagai berikut:

SGR berat $=\frac{\operatorname{Ln} W t-\operatorname{Ln} W 0 \times 100 \%}{T 1-T 2}$

Keterangan :

SGR: Laju pertumbuhan harian $(\%)$

W0 : Bobot ikan pada awal penelitian $(\mathrm{g})$

Wt : Bobot Ikan pada akhir penelitian $(\mathrm{g})$

T : Waktu

Data selanjutnya adalah menghitung FCR atau Feed Convention Ratio. FCR adalah suatu rasio yang menunjukkan jumlah pakan yang dibutuhkan untuk menghasilkan $1 \mathrm{~kg}$ ikan. FCR dapat dihitung dengan rumus Effendi (1997), yaitu:

FCR $=$ F $/(\mathbf{W t}-$ Wo $)$

Keterangan :

FCR : Feed Convertion Ratio

$\mathrm{F} \quad$ : Jumlah pakan yang dikonsumsi

W0 : Bobot ikan Bandeng pada awal penelitian (g)

Wt : Bobot ikan Bandeng pada akhir penelitian (g)

Survival Rate atau kelulushidupan ikan juga merupakan data penting yang dihitung dalam penelitian ini. Menurut Lucas et al. (2015), Survival Rate adalah merupakan indikator yang digunakan untuk mengetahui persentase sintasan pada ikan dalam masa pemeliharaan. Untuk menghitung SR menggunakan rumus:

$$
\begin{aligned}
& \mathbf{S R}= \mathbf{N t} \boldsymbol{N 0} \mathbf{1 0 0} \% \\
& \text { Keterangan : } \\
& \text { SR : Tingkat sintasan (\%) } \\
& \text { Nt : Jumlah total ikan yang masih hidup } \\
& \quad \text { sampai akhir penelitian } \\
& \text { N0 : Jumlah total ikan pada awal penelitian }
\end{aligned}
$$

Parameter kualitas air yang diukur pada penelitian meliputi suhu, $\mathrm{pH}$ dan salinitas.

Hipotesis dalam penelitian sebagai berikut:

$\mathbf{H}_{\mathbf{0}}$ : Penggunaan pakan yang telah diperkaya probiotik dengan dosis yang berbeda diduga tidak berpengaruh terhadap laju pertumbuhan ikan bandeng.

$\mathbf{H}_{1}$ : Penggunaan pakan yang telah diperkaya probiotik dengan dosis yang berbeda diduga berpengaruh terhadap laju pertumbuhan ikan bandeng

\section{Analisis Data}

Data yang diperoleh dari penelitian ini bersifat kuantitatif. Selanjutnya dilakukan uji statistik untuk menjawab hipotesis yang dibuat. Data yang diperoleh dari hasil pengamatan adalah data kuantitatif. Sebelumnya data diuji normalitas terlebih dahulu untuk mengetahui apakah data tersebar secara normal. Langkah kedua adalah menguji homogenitas data untuk menilai apakah data tersebut homogen atau tidak. Jika data terdistribusi normal dan homogen maka dilakukan uji sidik ragam atau ANOVA. Uji statistik ini digunakan untuk mengetahui pengaruh perbedaan perlakuan pada ikan bandeng. Selanjutnya untuk mengetahui terdapat perbedaan antara perlakuan dilakukan uji tukey. Data kualitas air yang diperoleh dianalisis secara deskriptif.

\section{HASIL DAN PEMBAHASAN 4.1. HASIL}

4.1.1. Pertumbuhan Benih Ikan Bandeng

Hasil pertumbuhan benih ikan bandeng tersaji pada tabel 1 .

Tabel 1 Hasil Laju Pertumbuhan Perlakuan

\begin{tabular}{ccccc}
\hline \multirow{2}{*}{ Perlakuan } & \multicolumn{3}{c}{ Ulangan } & \multirow{2}{*}{ Rerata } \\
\cline { 2 - 4 } & 1 & 2 & 3 & \\
\hline A & 8,3 & 7,2 & 7,7 & 7,73 \\
B & 9,26 & 9,5 & 9,38 & 9,38 \\
C & 9,76 & 10,05 & 10,1 & 9,97 \\
D & 10,72 & 11,14 & 10,61 & 10,82 \\
E & 8,4 & 9,25 & 9,32 & 8,99 \\
\hline
\end{tabular}

Pada tabel 1 menunjukkan bahwa laju pertumbuhan benih ikan bandeng sangat baik. Perlakukan D memiliki laju pertumbuhan terbaik yaitu 10,82 gram, kemudian perlakuan C memiliki laju pertumbuhan sebesar 9,97 gram, selanjutnya perlakuan B dengan laju pertumbuhan 9,38 gram, lalu perlakuan E 
dengan laju pertumbuhan 8,99 gram dan perlakuan A yang memiliki laju pertumbuhan terendah yaitu hanya 7,73gram.

\subsubsection{SGR Benih Ikan Bandeng}

Hasil laju pertumbuhan spesifik benih ikan bandeng tersaji pada tabel 2 .

Tabel 2 Hasil Laju Pertumbuhan Spesifik

\begin{tabular}{ccccc}
\hline \multirow{2}{*}{ Perlakuan } & \multicolumn{3}{c}{ Ulangan } & \multirow{2}{*}{ Rerata } \\
\cline { 2 - 4 } & 1 & 2 & 3 & \\
\hline A & 027 & 0,24 & 0,25 & 0,26 \\
B & 0,30 & 0,31 & 0,31 & 0,31 \\
C & 0,32 & 0,33 & 0,33 & 0,33 \\
D & 0,35 & 0,37 & 0,35 & 0,36 \\
E & 0,28 & 0,30 & 0,31 & 0,30 \\
\hline
\end{tabular}

\subsubsection{FCR Benih Ikan Bandeng}

Hasil pemanfaatan pakan ikan bandeng selama penelitian disajikan pada tabel 3 .

Tabel 3 FCR Ikan Bandeng

\begin{tabular}{ccccr}
\hline \multirow{2}{*}{ Perlakuan } & \multicolumn{3}{c}{ Ulangan } & \multirow{2}{*}{ Rerata } \\
\cline { 2 - 4 } & 1 & 2 & 3 & \\
\hline A & 1,80 & 1,95 & 1,89 & 1,89 \\
B & 1,69 & 1,63 & 1,65 & 1,66 \\
C & 1,57 & 1,55 & 1,53 & 1,55 \\
D & 1,48 & 1,47 & 1,51 & 1,49 \\
E & 1,82 & 1,66 & 1,64 & 1,71 \\
\hline
\end{tabular}

\subsubsection{Sintasan Benih Ikan Bandeng}

Selama penelitian tingkat kelulushidupan ikan bandeng yang dipelihara pada semua perlakuan sebesar $100 \%$ atau tidak terdapat kematian.

\subsection{PEMBAHASAN}

\subsubsection{Pertumbuhan}

Berdasarkan analisis ragam diperoleh bahwa hasil $\mathrm{F}$ hitung $(28,6950 * *)>\mathrm{F}$ tabel $5 \%$ $(3,48)$ dan $1 \%(5,99)$. Hal ini menunjukkan bahwa ada perbedaan pengaruh yang sangat nyata antar perlakuan yang diterapkan., sedangkan hasil analisis uji lanjutan uji tukey atau uji beda nyata jujur menunjukan bahwa perbedaan dosis probiotik berbeda sangat nyata. Hal tersebut menunjukkan bahwa pemberian probiotik dalam pakan buatan memberikan pengaruh terhadap pertumbuhan bobot benih ikan bandeng, di mana bobot tertinggi pada perlakuan $\mathrm{D}(15 \mathrm{ml} / \mathrm{kg}$ pakan) yaitu 10,82 gram, sedangkan bobot terendah pada A (kontrol) yaitu 7,73gram. Perbedaan pertumbuhan bobot tersebut diduga karena adanya perbedaan pemberian dosis yang berbeda probiotik dalam pakan buatan. Berdasarkan hasil analisa sidik ragam terdapat pengaruh yang sangat nyata pada pemberian probiotik dengan dosis yang berbeda terhadap pertumbuhn ikan bandeng. Peningkatan pertumbuhan ditunjukkan dari perlakuan A sampai perlakuan D seiring adanya penambahan dosis probiotik.

Hal ini dapat disebabkan karena probiotik mengandung Lactobacillus plantarum menghasilkan asam laktat di saluran pencernaan. Lactobacillus plantarum merupakan salah satu spesies dari bakteri asam laktat (BAL). Hal ini sejalan dengan Reddy et al (2003) yang menyebutkan bahwa Lactobacillus plantarum merupakan bakteri yang berperan dalam proses fermentasi yaitu menghasilkan asam laktat. Kehadiran asam laktat yang bersifat bakterisidal untuk bakteri patogen sehingga mampu menekan pertumbuhan bakteri pembusuk pada usus (Delgado et al.,2001) dalam Rostini (2007). Selain itu bakteri ini dapat menghasilkan enzim ektraselluter yang membantu enzim yang sudah ada di saluran pencernaan sehingga absorpsi makanan menjadi lebih besar. Enzim yang diproduksi adalah enzim proteolitik yang memiliki kemampuan merubah protein menjadi asam amino sehingga lebih mudah diserap tubuh. Bakeri Lactobacillus juga berperan membantu penyerapan vitamin dengan cara mensintesis vitamin dari nutrisi yang kompleks serta menyerap antioksidan sehingga mampu meningkatkan pertumbuhan dan melindungi ikan dari bahan yang berbahaya.

Proporsi bakteri probiotik dalam saluran pencernaan sangat penting dijaga agar proses pencernaan dapat tetap berjalan baik. Menurut Mulyadi (2011) proporsi jumlah koloni bakteri probiotik dalam pakan menyebabkan aktivitas bakteri probiotik dapat bekerja secara maksimal dalam pencernaan ikan. Kondisi ini menyebabkan daya cerna ikan pun menjadi lebih tinggi dalam menyerap sari-sari makanan . Namun pemberian probiotik terlalu tinggi tidak akan memberikan dampak positif pada pertumbuhan. Hal ini ditunjukkan pada perlakuan E (20 ml/Kg pakan) di mana terjadi penurunan pertumbuhan pada dosis probiotik tertinggi. Menurunnya pertumbuhan pada 
perlakuan E dapat disebabkan karena terlalu tingginya populasi bakteri sehingga menimbulkan persaingan pertumbuhan bakteri dalam pengambilan nutrisi atau substrat. Persaingan yang tinggi antar bakteri menyebabkan aktivitas bakteri pencernaan dalam usus menjadi terhambat. Hal ini mengakibatkan sekresi enzim pencernaan juga menurun (Gatesoupe,1999) dan berakibat menurunnya absorpsi makanan.

\subsubsection{SGR Benih Ikan Bandeng}

Laju pertumbuhan spesifik (Spesific Growth Rate) merupakan kecepatan pertumbuhan seiring pertambahan waktu (Rasidi,2012). Pertumbuhan yang meningkat pada perlakuan A sampai perlakuan D terjadi pada setiap sampling yang dilakukan. Hal ini menunujukkan bahwa pemberian probiotik sampai dosis tertentu mampu menyebabkan pakan yang diberikan termanfaatkan dengan baik oleh ikan. Pertumbuhan ikan dipengaruhi beberapa faktor baik internal maupun eksternal di antaranya: pakan, kualitas benih dan juga kualitas air. Nilai SGR tertinggi pada perlakuan D yang mencapai $0.36 \%$. Hal ini menunjukkan bahwa pemberian dosis probiotik $15 \mathrm{ml} / \mathrm{kg}$ pakan telah memberikan kecukupan nutrisi untuk pertumbuhan ikan. Nutrisi yang diserap oleh tubuh salah satunya adalah protein, akan digunakan untuk memperbaiki jaringan yang rusak sedangkan energi yang dihasilkan digunakan untuk pertumbuhan. Hal ini sejalan dengan Syahril (2011) bahwa pertumbuhan dan pembentukan jaringan tubuh paling besar dipengaruhi adanya keseimbangan protein dan energi dalam pakan.

\subsubsection{FCR Ikan Bandeng}

FCR merupakan perbandingan antara jumlah pakan yang dikonsumsi dengan pertambahan berat ikan bandeng. Menurut Fry (2016) standar nilai FCR pada ikan yang menggunakan pakan komersil sebesar 1,0 - 2,4. Hasil pengamatan menunjukkan bahwa rasio konversi pakan terbaik terdapat pada perlakuan D (15 ml/kg pakan) yaitu $1: 1,49$, dan pada perlakuan A (pakan tanpa penambahan probiotik) menunjukkan rasio konversi pakan sebesar 1:1,89 yang merupakan yang terendah dibandingkan dengan perlakuan lainnya. Hal ini diduga karena pakan yang ditambahkan dengan probiotik dapat mempengaruhi nafsu makan ikan. Menurut Putri et al (2014) menyatakan bahwa pakan yang diberikan probiotik beraroma lebih segar dibanding yang tidak diberi probiotik. Aroma segar ini akan membuat nafsu makan ikan meningkat dan menyebabkan meningkatnya asupan pakan. Bau segar dan rasa yang berbeda pada pakan yang diberikan probiotik menjadi atraktan bagi ikan untuk mendekati pakan dan akhirnya mengkonsumsi pakan tersebut. Menurut Afrianto dan Liviawati (2005) menyatakan bahwa pemberian jenis dan jumlah atraktan yang tepat akan mampu meningkatkan konsumsi pakan oleh ikan.

Kualitas pakan yang meningkat karena pemberian probiotik juga mempengaruhi nilai FCR menjadi lebih rendah. Menurut Susanti (2004) nilai konversi pakan yang rendah berarti kualitas pakan yang diberikan baik. Sedangkan bila nilai konversi pakan tinggi berarti kualitas pakan diberikan kurang baik. Kehadiran probiotik memiliki manfaat untuk mempebaiki efisiensi pakan dengan cara memproduksi enzim-enzim yang berperan dalam pencernaan. Hal ini sesuai pendapat Sakamole et al (2014) bahwa probiotik membantu meningkatkan proses pencernaan dengan melepaskan enzimenzim pencernaan dan menghalangi pertumbuhan mikroorganisme patogen dalam usus. Jenis enzim pencernaan yang diproduksi seperti selulose, amylase dan protease. Amylase berfungsi mengubah karbohidrat menjadi gula. Selulose merupakan enzim yang mengubah selulosa menjadi ikatan glukosida sederhana dan protease mengubah protein menjadi asam amino. Nutrisi dalam bentuk yang sederhana membuatnya lebih mudah diserap tubuh

Pakan menjadi salah satu faktor penting untuk meningkatkan pertumbuhan. Kualitas pakan yang baik yaitu mengandung nutrisi yang dibutuhkan sesuai dengan kebutuhan ikan. Pakan yang baik ialah pakan yang sesuai kebutuhan (Rosmawati et al. 2019), memiliki nilai gizi, tepat waktu dan tepat dosis (Mulyana dan Rosmawati, 2019) sehingga mampu menghasilkan pertumbuhan yang optimal. Sesuai dengan hasil penelitian, perlakuan D menunjukkan pakan yang diberikan lebih efisien dibandingkan dengan perlakuan lainnya. 


\subsubsection{Survival Rate}

Tingkat kelangsungan hidup ikan bandeng pada semua perlakuan memberikan hasil yang baik yaitu $100 \%$. Hal ini menunjukkan tidak adanya pengaruh perbedaan dosis probiotik pada kelangsungan hidup ikan. Survival Rate dapat dipengaruhi beberapa faktor yaitu kualitas pakan, kualitas benih dan juga kualitas air yang baik. Pemberian pakan yang telah mengandung nutrisi yang cukup dapat membantu meningkatkan kemampuan ikan untuk bertahan hidup. Hal ini sesuai dengan pernyataan Prasetyo et al, (2018) bahwa kelangsungan hidup akan tinggi apabila didukung faktor kualitas dan kuantitas pakan yang sesuai serta kualitas lingkungan yang baik.

\subsubsection{Kualitas Air}

Faktor penting dalam kegiatan budidaya ikan adalah kualitas air. Air merupakan media hidup ikan (Sitompul dkk., 2012). Sebagai media hidup ikan, kondisi kualitas air harus sesuai bagi kehidupan ikan karena dapat mempengaruhi produksi budidaya. Menurut Landau (1992) bahwa kualitas air dapat mempengaruhi kesehatan ikan dan produktivitas budidaya. Kondisi kualitas air yang baik akan meningkatkan laju pertumbuhan ikan. Sebaliknya kualitas air yang buruk akan menyebabkan ikan stres dan menurunkan pertumbuhan. Hal ini sesuai dengan pendapat Djatmika (1986) yang menyatakan bahwa kualitas air dapat memberikan pengaruh terhadap pertumbuhan ikan.

Selama penelitian ini dilakukan pengukuran kualitas air dilakukan selama 3 hari sekali yang meliputi salinitas, suhu, dan pH. Hasil pengamatan kualitas air selama penelitian menunjukkan hasil yang baik. Parameter temperatur antara $26-30^{\circ} \mathrm{C}, \mathrm{pH}$ air berkisar antara 7,2-7,6, dan salinitas 20 ppt. Nilai parameter kualitas air tersebut sudah sesuai dengan standar optimal kualitas air yang sudah ada seperti suhu yang baik untuk ikan Bandeng adalah $27-30^{\circ} \mathrm{C}$ (Effendi, 2003) dan salinitas yang baik untuk pertumbuhan ikan bandeng adalah 26-30 ppt (Poernomo, 1988). Untuk $\mathrm{pH}$ air juga telah memenuhi range nilai yang ditentukan yaitu 7 - 8. Menurut Gufron dan Kordi (2007) pergantian air perlu dilakukan untuk mengantisipasi perubahan pada kualitas air. Jika $\mathrm{pH}$ terlalu rendah atau asam perlu dilakukan pengapuran pada kolam maupun tambak.

Keberadaan bakteri Nitrosomonas dalam probiotik memberikan peranan penting dalam menjaga kualitas air. Nitrosomonas merupakan bakteri yang berperan untuk mengoksidasi amoniak menjadi nitrit dan kemudian dirubah ke senyawa nitrat (Lufisari et al, 2015). Hal ini menyebabkan kadar amoniak dalam air selalu terjaga dengan baik. Begitu pula dengan kehadiran bakteri Bacillus yang juga mampu membantu pertumbuhan dan menjaga kestabilan kualitas air. Bacillus sp selain mengeluarkan enzim selulose, amylase dan protease yang berperan dalam pencernaan, juga memiliki kemampuan mendegradasi bahan organik dalam perairan (Karigar and Rao,2011) sehingga kadar amoniak dapat ditekan. Kadar amoniak yang tinggi akan menyebabkan kematian bagi ikan.

\section{SIMPULAN DAN SARAN \\ 5.1. Simpulan}

Berdasarkan hasil penelitian dapat disimpulkan bahwa:

a. Penambahan probiotik pada pakan dengan dosis yang berbeda memberikan pengaruh sangat nyata terhadap pertumbuhan ikan bandeng.

b. Penambahan probiotik dengan dosis 15 $\mathrm{ml} / \mathrm{kg}$ pakan mampu memberikan peningkatan tertinggi terhadap pertumbuhan ikan bandeng sebesar 10,82 gr.

\subsection{Saran}

Disarankan untuk pembudidaya menggunakan dosis maksimal pemberian probiotik dengan dosis $15 \mathrm{ml} / \mathrm{kg}$ dalam pakan ikan bandeng.

\section{REFERENSI}

Afrianto, Eddy dan Evi Liviawaty. 2005. Pakan Ikan. Yogyakarta: Kanisius.

Agustini, M. Muhajir. 2018. Efek Penambahan Probiotik Petrofish pada Pakan Komersil terhadap Pertumbuhan Berat Mutlak Benih Ikan Nila Srikandi (Oreochromisaureus $x$ niloticus). [Penelitian] FakultasPertanian, 
Universitas Dr. Soetomo Surabaya.

Alifuddin Muhammad. 2003. Pembesaran Bandeng. Modul Penebaran Nener. Direktorat Pendidikan Menengah Kejuruan. Direktorat Jenderal Pendidikan Dasar dan Menengah. Departemen Pendidikan Nasional.

Cruz, P. M., A.L. Ibanez, O.A.M Hermosillo and H.C.R. Saad. 2012. Use of Probiotic in Aquaculture.ISRN Microbiology.

Djatmika, A. 1986. Parameter Kualitas Air. Usaha Nasional. Surabaya.

Effendi, M. I. 1997. BiologiPerikanan. YayasanPustaka Nusantara, Yogyakarta. $162 \mathrm{hlm}$.

Effendi, Hefni. 2003. Telaah Kualitas Air Bagi Pengelolaan Sumber Daya dan Lingkungan

Elumalai, M. Antunes C., Guihernio L. 2013. Effects of Single Metals and Selected Enzymes Of CarcinusMaens Water, Air. And Soil Pollution. 141 (1-4); 273-280.

Fry JP. 2016. Environmental health impacts of feeding crops to farmed fish Environ. Int. 91 201-14.

Gatesoupe FJ 1999. The Use of Probiotics in Aquaculture. Aquaculture. 180: 147-165

Ghufron. M, dan H. Kordi. 2007. Pengelolaan Kualitas Air. Rineka Cipta. Jakarta

Irianto, A. 2003. Probiotik Akuakultur. Cetakan I. Penerbit Gadjah Mada University Press. Bulaksumur Yogyakarta. $125 \mathrm{pp}$..

Iribarren, D., P. Daga, M. T. Moreira and G. Feijoo. 2012. Potential Environmental Effects of Probiotics Used in Aquaculture. Aquacult. Int., 20 :779-789.

Karigar CS, Rao SS. 2011. Role of microbial enzymesin bioremediation of pollutans: A review. Enzyme Research. 2011: 1 $\square 11$. http://doi.org/bt8kvp

Kordi, G. 2009. Budidaya Perairan. Citra Aditya Bakti, Bandung.

Landau, Matthew. 1992. Introduction to
Aquaculture. John Willey and sons Incorporated. New Jersey. USA

Lucas, F.G.W., Kalesaran J.O, Lumenta C. 2015.Pertumbuhan dan Kelangsungan Hidup Larva Gurami (Osphronemus gourami) dengan Pemberian Beberapa Jenis Pakan. Jurnal Budidaya Perairan,. 3(2) 19-28.

Lufisari Herdianti, Kardawan Soewardi and Sigit Harriyadi. 2015. Efektivitas Penggunaan Bakteri Untuk Kualitas Air Media Budidaya Udang vaname (Litopanaeus vannamaei)Super Intensif. Jurnal Ilmu Pertanian Indonesia. Vol 20 (3). Hal 265-271

Mulyana dan Rosmawati. 2019. Supplementasi Rosella (Hibiscus sabdariffa LINN) dalam Pakan Buatan terhadap Kinerja Benih Ikan Nilem(Osteochilushasselti). Jurnal Mina Sains 5(1): $24-30$.

Mulyadi, A.E. 2011. Pengaruh Pemberian Probiotik pada Pakan Komersi lterhadap Laju Pertumbuhan Benih Ikan Patin (Pangasiushypophthalamus). Skripsi. Fakultas Perikanan dan Ilmu Kelautan. UNPAD: Jatinangor.

Putra, A. N. 2010. Kajian Probiotik, Prebiotik dan Sinbiotik untuk Meningkatkan Kinerja Pertumbuhan Ikan Nila (Oreochromis niloticus). [Tesis]. Program PascaSarjana. InstitutPertanian Bogor. Bogor. $91 \mathrm{hlm}$.

Putri Noviana, Subandiyono dan Pinandoyo. 2014. Pengaruh Pemberian Probiotik dalam Pakan Buatan Terhadap Tingkat Konsumsi Pakan dan Pertumbuhan Benih Ikan Nila (Oreochromis Niloticus). Jurnal Of Aquaculture Management and Technology. Vol 3 No 4. Hal 183-190

Prasetio, E., Rachimi, dan Hermawansyah, M. 2018. Penggunaan Serbuk Lidah Buaya (Aloe vera) dalam Pakan Sebagai Immmunostimulan Terhadap Hematologi Ikan Biawan (Helostoma teminckii) yang Diuji Tantang dengan Bakteri Aeromonas hydrophila. Jurnal Ruaya. Vol 6 (1)

Poernomo, Alie. 1988. Faktor Lingkungan Dominan pada Budidaya Bandeng Intensif. 
Makalah Seminar Usaha Budidaya Tambak di Jawa Timur, Surabaya

Rasidi. 1998. Formulasi Pakan Lokal Alternatif untuk Unggas. Penebar Swadaya, Jakarta.

Rasidi. 2012. Pertumbuhan, Sintasan, dan Kandungan Nutrisi Cacing Polychaeta nereisdi versicolos (O.F.Muller, 1776) yang Diberi Jenis Pakan Berbeda dan Kajian Pemanfaatan Poluchaeta oleh Masyarakat Sebagai PakanInduk di Pembenihan Udang. Tesis. Program Pasca Sarjana. Universitas Indonesia. Jakarta. 107 hal.

Reddy, G.M., Altaf, B.J. Naveena, M. Venkateshwar, E. danKumar,V. (2008). Amylolytic Bacterial Lactic Acid Fermentation, a review. Biotechnology Advances 26: 22-34

Rosmawati, Mulyanadan Muhammad Azmi Rafi. 2019. Pertumbuhandan Kelangsungan Hidup benih Lobster Ikan air Tawar(Cheraxquadricarinatus) Yang di Beri Pakan Buatan Berbahan Baku Keong mas (Pomaceasp). Jurnal Mina SainVol 5 No 1. 31-41

Rostini, lis. 2007. Peranan Bakteri Asam Laktat (Lactobacillus plantarum) terhadap Masa Simpan Filet Nila Merah pada Suhu Rendah. Laporan Penelitian. Fakultas Perikanan dan Kelautan UNPAD

Sakamole, E.T., C. Lumenta\& M. Runtuwene. 2014. Pengaruh Pemberian Probiotik Dosis Berbeda dalam Pakan terhadap Pertumbuhan dan Konversi Pakan Benih Ikan Mas (Cyprinuscarpio). Buletin Sariputra. 1 (1): 29-33

Septiarini, Esti Harpeni dan wardiyanto, 2012. Pengaruh Waktu pemberian Probiotik Yang Berbeda Terhadap Reson Imun Non Specifik Ikan Mas (Cyprinus carpio) Yang Di Uji Tantang Bakteri Aeromonas salmonicida. Jurnal rekayasa Dan Teknologi Budidaya Perairan. Vol 1 No 1. Hal 40-46.

Sitompul, S.O., E. Harpeni., dan B. Putri. 2012. Pangaruh Kepadatan Azolla sp. yang Berbeda terhadap Kualitas Air dan
Pertubuhan Ikan Lele Dumbo pada Sistema Tanpa Ganti Air. Jurnal Rekayasa dan Teknologi Budidaya Perairan. Vol.1:1. Oktober.2012

Susanti, D. (2004). Pengaruh Penambahan Berbagai Silase Produk Perikanan dalam Ransum Pakan terhadap Pertumbuhan dan Kelulushidupan Benih Ikan Nila Gift. Skripsi. Semarang, Indonesia: Universitas Diponegoro

Syahril, R. K. 2011. Pemanfaatan Fermentasi Ampas Tahu Dalam Pakan Terhadap Pertumbuhan Benih Ikan Baung (Mystus nemurusC.V). Skripsi Fakultas Perikanan Dan Ilmu Kalautan Universitas Riau. Pekanbaru. (tidak diterbitkan)

Yanti, Z., Z. A. Muchlisin, Sugito. 2013. Pertumbuhan dan Kelangsungan Hidup Benih Ikan Nila (Oreochromi niloticus) pada Beberapa Konsentrasi Tepung Daun Jaloh (Salix tetrasperma) dalam Pakan. Journal of Fisheries and Aquatic Sciences. 2(1): $16-19 \mathrm{hlm}$. 